\title{
AN INTERVIEW WITH ELLEN MEIKSINS WOOD
}

After several years spent working closely with the magazine, Ellen Meiksins Wood-the historian and critic of political theory-officially joined Harry Magdoff and Paul Sweezy in March 1997 to become the first new editor of Monthly Review in thirty years.

Born Ellen Meiksins in New York in 1942, a year after her parents arrived as political refugees, she was raised in the United States and Europe. She received a B.A. in Slavic languages from the University of California at Berkeley in 1962 and subsequently entered the graduate program in political science at the University of California, Los Angeles, from which she received a Ph.D. in 1970. From 1967 to 1996, she taught political science at York University in Toronto, Canada.

Wood is the author of six books: Mind and Politics: An Approach to the Meaning of Liberal and Socialist Individualism (University of California Press, 1972), The Retreat from Class (Verso, 1986), Peasant-Citizen and Slave (Verso, 1988), The Pristine Culture of Capitalism (Verso, 1992), Democracy Against Capitalism (Cambridge University Press, 1995), and The Origin of Capitalism (Monthly Review Press, 1999). With her husband Neal Wood, she is author of two more books: Class Ideology and Ancient Political Theory (Oxford University Press, 1978) and $A$ Trumpet of Sedition: Political Theory and the Rise of Capitalism, 1509-1688 (New York University Press, 1997). Finally, with various colleagues, she is co-editor of the collections In Defense of History (1997), Capitalism and the Information Age (1998), and Rising from the Ashes? Labor in the Age of "Global" Capitalism (1998), all from Monthly Review Press. Wood served on the editorial committee of the British socialist journal New Left Review between 1984 and 1993, and she won the Isaac Deutscher Memorial Prize for her book The Retreat from Class in 1988.

The following interview was conducted by Christopher Phelps in New York City on November 23, 1998.

\section{ARRIVING AT MONTHLY REVIEW}

Q: You are only the fourth editor of MR in its fifty years of publication. How did that come about? 
WOOD: I don't know how it happened, really. It just sort of gradually emerged.

I had met Harry and Paul before at the Socialist Scholars Conference in New York, but the first time I spoke to either of them at any length, really, was at one of the international conferences of socialists lield at Cavtat in Yugoslavia. It was the last one held before the whole thing - the country, not just the conference-folded up. Harry and Paul used to go to those conferences regularly, and Harry and Beadie had a tradition of inviting people to their hotel room for drinks and talk. Those get-togethers were a major feature of the conference, certainly for me. At the conference's closing dinner, I found myself sitting next to Harry, and he started ruminating about the future of MR and how hard it was going to be to find someone to take over. That was the first time I ever had occasion to think about MR in those terms. But I don't think the idea that it might be me ever crossed his mind, and it certainly didn't cross mine.

The first thing I ever wrote for MR was a very unlikely thing, a review of a book on Julius Caesar. My next piece was on the history of the market. After that, I came onto an informal editorial committee for the magazine, and one thing led to another-not least, I should say, a warm personal relationship.

\section{Q: So it was, from your standpoint, a natural fit?}

IVOOD: Yes, though I have to admit that I took on the job with great trepidation, because I very much want to continue my own writing, and the job is a big responsibility.

I'olitically, I can't think of anything that would have been better. Having had years on the New Left Review, I was in a particularly good position to understand how important the MR project was. There's just nothing else like it. NLR had a lot of things going for it; it was intellectually challenging, and so on. But politically it was never very satisfying. One of the most notable things about NLR, for example, the whole time I was on the board was that even though some of the most important eruptions of working-class militancy occurred-the miners' strike, then the big Wapping strike-you'd hardly have noticed that these things were taking place if you read the New Left Review. I wrote an internal document once complaining about this sort of thing, doing a content analysis of the past decade or so of articles. The absence of the working class was really quite remarkable. That, for me, is one of MR's most important achievements right now: our coverage of the labor movement and our building of links with the labor left. 
Q: All of this raises the fact that it was possible for you to come on board at MR, too, because you were no longer on the NLR editorial committee.

WOOD: Yes, and in that sense MR was an unparalleled opportunity for somebody like me. I was definitely looking for another political outlet after NLR, and my political interventions are mainly my intellectual work, my writing. I don't say that writing is the most important thing for somebody to be doing. Far from it. But it's something that does need to be done, and it's what I do best.

\section{RED DIAPERS}

Q: Did you inherit your politics?

WOOD: In a manner of speaking, yes. My parents were both Bundists who came to this country as political refugees, which saved them from succumbing to the fate of other European Jews, including manv members of their families. They came to the United States in 1941, after fleeing Latvia in the late 1930s because my father, who was a leader of a socialist youth organization, was about to be arrested. Other members of his group were arrested when Latvia's indigenous fascists came to power. I was born in New York during the war.

\section{Q: So it was a political household?}

WOOD: I grew up surrounded by left-wing ideas. Not just from :ny parents but also my father's uncle, who I think sponsored my paren ts. immigration, and who was editor of the Jewish socialist magazine Der Vecker. I spent a lot of time in my earliest years at his place, because my mother worked. Not long after my parents came to the United States, she went to work for the Jewish Labor Committee, so some of the first people I remember, apart from my own family, are people from the labor movement.

After the war-my parents had separated by then-my mother was sent to Germany by the JLC to work with displaced persons. Sine spent four or five years there, while I went to boarding schorl, partly in the U.S. and partly in Europe. I don't think that rny mother ever stopped thinking of herself as a socialist. But when she came back to the United States and we settled in California, she became, I have to confess, a Democratic Party activist. She was also a member of the NAACP.

My father, who went to work for the United Nations, remains a Marxist to this day. He is a committed MR reader, but he has his own very distinct views, especially about capitalism. He likes to say that I'm 
closer than anybody else to the truth, but I'm afraid I'm disappointing him in the exchanges we have by not quite getting it. [Laughs.]

\section{CANADIAN VANTAGE}

(): You moved to Canada in the late sixties, a time when there was a rising level of movement activism, both there and in the United States. How do you think that living in Canada affected your thought?

WOOD: Canada was an interesting vantage point, because it's so close to the United States, and in some ways sixties culture was the same, and yet at the same time, it gave you a kind of critical distance which people in the United States simply didn't have. Canada was in some ways a partner of U.S. imperialism, but it also stood apart.

Our students were doing things that sixties students were doing in the United States. We had demonstrations and teach-ins about the war. But Canada was also a haven for draft resisters. Neal and I had draft resisters staying in our apartment-including, by the way, Neal's son. And a lot of people who came to Canada to teach or do other things were Americans who came because of the war.

Many Canadians were coming to define their national identity against U.S. hegemony. A lot of Canadian academics were beginning to get very nervous about this influx of Americans and were adopting a nationalist position. I understood, in one sense. But one of the first things that Neal and I published after we came to Canada wis an article on the Americanization of political science for a book on the Americanization of the Canadian universities. Our main point was what's the point of making this a national issue, if the way Canadians were going to do political science was thoroughly imbued with the same ideological and methodological principles that were dominant in the United States? It was a kind of minilesson in the limits of nationalism.

Although our own university department began by self-consciously molding itself as American-style political science, behaviorism and so on, for some peculiar reason in a very short time it turned into the most Marxist department in North America, probably in the universe. That meant a lot, in terms of my own intellectual development. I couldn't have gotten to first base with the work I was doing in any American university that I can think of, let alone get tenure. No question: my intellectual development would have been entirely cifferent if I'd been teaching in an American university.

Plus, in many ways, though I hate to say it, the United States is a very provincial place, not in spite of its position in the world but because of it. It's as if the United States, this superpower, is the center of the universe. It is so centered on itself and is hardly aware that the rest of the world exists, except when it impinges on it in some sort 
of very direct way. Just look at the TV news, or, for that matter, the New York Times. In Canada, you were more open to other parts of the world. There was a lot more day-to-day international consciousness. Quite apart from the fact that Canada had a mildly left: mainstream tradition that the United States doesn't, a social-democratic party, and so on, and a proportionately larger and more militant organized labor movement.

\section{GENERATIONS OLD AND NEW}

Q: In an essay in the 1995 Socialist Register, you take up the British new left - the first new left, you call it - whose experience was formed by the Depression, fascism, and the Second World War. This inclucles people like Ralph Miliband and, especially, dissident Communists like E. P. Thompson and John Saville, who became critical of Stalinism yet remained to the left of social democracy and retained a commitment to the labor movement and class politics. They formed a tradition that, I take it, you find congenial and find yourself operating within, even though you belong to a different generation.

WOOD: Yes. The point about the two generations, the first and second new left in Britain, is about different approaches to capitalisın. There's nothing magical about generations, of course. But this generational shift corresponded to a real historical rupture. I was struck by the differences between the generation that came io political consciousness during the Depression and war, and the one that grew up in the so-called golden age of capitalism, the long post-war boom. These two generations had such different conceptions of what was normal for capitalism. For one, it was depression and war. For the other, it was prosperity and so on, even if a lot of people were excluded.

This was, by the way, particularly interesting in the case of Britain, because the second new left-especially the one associated with NLR - developed a whole analysis about British exceptionalism based on the assumption that British capitalism must be somehow defective because it wasn't quite sharing in the prosperity of other advanced capitalist countries. In other words, what was wrong with Britain, the reason it was in decline, wasn't so much capitalism but the wrong kind of capitalism. That's the kind of argument I set out to challenge in my book The Pristine Culture of Capitalism.

Anyway, that generational shift played out differently in the U.S., but the same division is there, too, between people for whom economic depression and war represent capitalist normality and people shaped by the postwar "golden age." 
Q: It occurred to me that while in Britain it's called the first new left, in the United States the analogue is Monthly Review, even if it's seen as an old left journal here. Its editors, too, were people whose generational experience was formed by the Depression, fascism, and the Second World War, who were drawn to and were for a time in very sympathetic connection to the Communist movement, yet were eventuilly led to go beyond that politics and have nevertheless remained on the left of the left. But not many people would put Edward Thompson, Paul Sweezy, and Harry Magdoff in the same grab-bag.

WOOD: No, they'd probably think of C. Wright Mills, or someone like that, as the first generation in the United States.

Q: But that's the whole difference. Mills said, "Give up Marx and the "labor metaphysic.' "

WOOD: Exactly, exactly. Another first-generation new left intellectual who comes to mind here, though he was a transplanted American, is Herbert Marcuse. He too regarded students and intellectuals as the revolutionary vanguard because he thought the working class had been thoroughly absorbed by consumer capitalism. But the new left in Britain wasn't, couldn't be so detached from the labor movement. They thought that socialist intellectuals had to take on new forms of intellectual and cultural struggle, because of the effects of consumer capitalism. But the working class stayed at the center of their intellectual and political project in a way that it didn't for the L.S. new left. So I think that your suggestion that the editors of MR had something essential in common with the British first new left is interesting. Some of those commonalities may be obscured by MR's interest in Maoism, which was pretty alien to the British new left, but in general I find the point useful.

Q: You seem an exception to the generational shift you're talking about, in that you belong to the generation of the postwar boom yet you have these affinities with an earlier left generation. Is it your engagement with British Marxism, the influence of your parents, or what? You yourself never experienced the Depression or the Second World War, except refracted through childhood.

WOOD: I suppose it's true that people like me, first-generation children of immigrant parents who lost many members of their family in the Holocaust and war, who fled fascism, and so on, have a more direct continuity with the experience of that generation. I also saw the palpable results of the war when I went to Germany with my mother as a small child. I went there, and to boarding school, because 
my mother, obviously because of her own experience and wat happened to her family, felt a need to do the job she was sent there to do for the Jewish Labor Committee.

So in all these ways my experience was shaped by that, but my point about generational shifts really has to do with the different approaches to capitalism, and I just happen to find the approach of ihe first new left, both British and MR, more convincing. The way capi-talism is shaping up today, that first new left seems a lot more up to date. It certainly has a lot more to tell us about the way things are now' than those who followed them-not just more than the second new left, but an awful lot more than the later postmodernist left, which is completely out of its depth in the current global crisis.

Q: To return to a point, then, it's as if there's not going to be a generational shift at $\mathrm{MR}$, so much as the passing of the torch generationally.

WOOD: If what you're saying is I'm not typical of my generation, maybe so. But I don't want to overdo it. After all, I was born and grew up mostly in the United States, and I experienced many of the same things that others of my generation did. I feel politically close to an earlier left, but it still matters that I grew up in a particular moment and place. And it matters for the magazine that the intellectual an $d$ political culture of the left today is still pretty much rooted in the one created by people of my generation.

Q: You mean the culture of the "golden age" of capitalism-namely, the prospect or illusion of permanent and universal affluence?

WOOD: Maybe the existence of affluence and the illusion of the possibility of its universality, because obviously there was a darker reality, which this generation of the left perceived in a particularly dramatic way. They realized that there were whole sections of the population that were being excluded, and that's what their oppor sition mainly focused on.

In the stuff that I've been writing, I've emphasized the "golden age" of capitalism as the shaping influence and suggested that, with some exceptions, the mainstream of the sixties left was not made up of revolutionary socialists. Sixties radicals were, in a way, shaped by the apparent success of capitalism instead of its failures. They thought that welfare and consumer capitalism were here to stay in some form or another, but they recognized that some people were excluded. Inclusion of those who were excluded was probably more: central to their view of the world than a complete transformation of the capitalist system or something that we would recognize as 
socialism, even if they called themselves socialists. I don't know how many of them had a clear view of anything more than a more democratic, non-imperialist, and non-racistcapitalism.

The negative side of that picture is that they often didn't have a clear perception of capitalism. The positive side, which maybe I haven't emphasized enough, is that it focused their attention on those excluded groups, in ways that earlier generations of the left hadn't. I don't want to go too far with that, because I don't buy the view that the old left, traditional Marxists, were not interested in race and gender oppression. On the contrary, I would take strong exception to the view that Marxists took second place to anyone on these questions. But it's true that my generation focused on them in a way that hadn't been done before. In a way, that's the up side of their failure, the virtue of their vice: by not taking the full measure of capitalism but focusing on the people who were excluded from its tenporary prosperity, they could do the most positive things that they clid, especially in anti-racist and anti-imperialist struggles.

Another point is that while in the fifties, the so-called golden age, you had a picture of general middle-class prosperity, on the other hand you had the Cold War. I went to school at a time when we we having regular air raid drills and had to sit in the corridors, learning how to supposedly protect our eyes and heads from the atom bomb. Now that was a really effective ideological strategy. This was a period when certain books were banned from libraries, books by Howard Fast and others. You've got to think that the anti-socialist ideology penetrated really deeply and also shaped the whole generation after mine.

One of my first and most dramatic political memories is a big NAACP rally at Shrine Auditorium in Los Angeles, a huge venue, held in nemory of Emmett Till, the black teenager who was murdered in Mississippi in 1955 . I vividly remember this rally at which his great uncle, a preacher, who he had been staying with when he traveled down from Chicago, was the main speaker. I obviously couldn't have known that this murder would represent a pivotal moment in the development of the civil rights movement, but it says a lot about the rensions of the times in which my generation grew up.

In one way or another, these things, taken together, were impinging on people's minds. On the one hand, you're surrounded by the prosperity of capitalism. On the other hand, you notice the exclusions from it. You know, Ozzie and Harriet on TV, and at the same tine Emmett Till is murdered. And all the while, you have the main alternative, socialism, ruled out in the most decisive possible way, presented as the incarnation of evil. 


\section{MOVEMENTS AND CLASS POLITICS}

$\mathrm{Q}$ : The issues that you're describing that generation being concerned about are the issues of the so-called new social movements-that is, anti-racism, feminism, ecology, the anti-war and anti-nuclear movements, all movements that were not confined to the labor movement and that often sat uneasily with the existing labor movement. The rap on people like yourself, in some circles, is that you're a class fundamentalist, inattentive to these sorts of concerns.

WOOD: There are several different ways of approaching this. One is to start from the premise that the fundamental reality in the world in which we live is capitalism. What is the constitutive relationship of capitalism? Class. Without the class division between capital and labor, you have no capitalism. It's as simple as that. If by some miracle we could get rid of racial and gender oppression, capitalism could still exist. None of these other relationships are constitutive of the sysiem in the same way. So I've never been able to think myself out of the view that if the system is to be transformed, we have to go to the root of its constitutive relationship. But I have never believed that there's anything inevitable about it. I've summed up my position in this way more than once: if it doesn't happen by means of the self-emancjpation of the working class, it's not going to happen at all.

Secondly, I have never taken the view that the working class consists of white, male, industrial blue-collar workers, and I know of no sophisticated Marxist who has ever thought that. I think that the old left got a bad rap on that, too. If you look at the history of the United States, no movement has been as consistent in its struggle for racial emancipation, the emancipation of women, and so on, as the socialist movement. Now, I'm not going to say that there haven't been huge omissions, or that the social movements haven't taught us lessons that we have to learn. But I think we have to keep that history in mind.

You can say that one side of the bringing together of whatever you want to call it -say, identity politics-and class politics is that it has always been necessary for the working class to take into account its diversity. It has never succeeded in anything it's done and will never succeed in anything it seeks to do without taking into account diversity. That's one side of the issue, but you can't say it's the only reason we: ought to be interested, simply because it's the only way of creating unity in the working class. It's an important reason but obviously not the only reason. Socialists have to have a deep-seated commitment to all forms of human emancipation, period.

The other side of the coin is that I don't know that any of these other particular struggles will succeed on their own. I do believe that: capitalism can tolerate a degree of formal equality among races and 
sexes that no previous system was able to do. But capitalism can make use of various inequalities besides its own constitutive class inequalities, and that's a profoundly important part of it. It has much to gain from dividing the working class. It has much to gain from constituting underclasses. These things also have profound ideological effects: people are able to think of the deprivations of capitalism as caused by anything and everything but capitalism itself. So capitalism has many reasons for making use of historic differences and oppressions which predate it, but which it can ap] ropriate to its own purposes. That's why struggles against these oppressions have to be anti-capitalist, in the end.

\section{CLASS: RETREATS AND RETURNS}

(1: All of this, then, gets to the heart of your criticism of postmoderrism, which celebrates-or calls unavoidable-difference, fragmentation, and so forth. I take it you would think of postmodern social theory, at least in academic circles, as being the highest form of the raw thought of this generation that we've been discussing. You came to light, I think, for many people with The Retreat from Class, a polemic against defectors from Marxism who were moving in a postmodernist direction at a time when that seemed to be the direction.

WOOD: Yes, I consider post-Marxism self-defeating from the standpoint of its own emancipatory projects, both in strategic and ideological terms. I recently wrote a preface for a new edition of The Retreat from Class. When I looked back over the book, I was really struck by the contradictions in post-Marxism. On the one hand, these postMarxists were emphasizing fragmentation, difference, all the rest of it that we now associate with postmodernism, and rejecting class politics and the universalistic politics we associate with Marxism. On the other hand, there was still something really universalist about what these post-Marxists were saying, in an abstract sort of way.

What I realized was that at that stage in the development of postMarxism, people like Ernesto Laclau and Chantal Mouffe were still trying to invoke what looked like universalistic principles, such as the notion of "radical democracy," but they had to do it in an empty, abstract way because their project had no social foundation. They did go a long distance in fragmenting the project, in separating struggles, in talking about class as too totalizing a concept, and so on. But they still, at that stage, thought of themselves as socialists and were looking for some lowest common denominator with which to bring these projects together, although they had undermined any social foundation for bringing them together. "Radical democracy" was the most vivid example of a completely abstract and vacuous idea, a lowest common denominator into which you could fit all these different 
struggles. So post-Marxism was attacking Marxist universalism and totalizations, but it was coming up with a much more abstract universalism, much less grounded in historical specificity than Marxismu is. Next, postmodernists dissolved even that vague kind of universalism, so that there was nothing left. All you have now is fragmentation and difference.

I'm all in favor of celebrating the diversity of human beings. In fact, I think the strength of the Marxist project is that it does recognize difference, specificities, and grounds its project in a real social world, but that it has a unifying principle-class-based upon lived experience. Obviously class can't cover all emancipatory struggles, but it can provide some sort of unifying principle among emancipatory struggles that's completely lacking in the postmodernist perspective. It can bring together women and men, black and white, based on their common experience of work and exploitation and common interest in a classless society. Incidentally, this common class project, this common anti-capitalist project, seems to me much more substanial and meaningfully democratic than the post-Marxist conception of radical democracy. The democratic project I'm talking about not only connects to concrete social realities but also demands the penetration of popular power into those huge spheres of life which capitalism seals off from democracy, all those spheres controlled either directly by the power of capital or indirectly by the so-called laws of the market.

But of course class unity and struggle don't come automatically. They require lots of work, political, organizational, and intellectual.

Q: Do you have a sense that class is coming back now, even in the universities? You have written that the conjunction of the ebbing of the sixties movements with a downturn in the advanced capitalist economies was the particular moment of take-off for postmodernism. As the prospects for radical change diminished, these flights of farcy became more voguish. Now we're at a different conjuncture, with evidence of even more profound instability in the world economy, combined with what seem to be new pulses of life in world labor movements, although that's an uneven process. So you have Jacques Derrida saying that Marx is back, and Richard Rorty calling for a return to class politics.

WOOD: Right, and even Judith Butler is making some nervous noises.

Q: Yet doing it in a way that sneaks class in the back door while retaining a good part of their old method. 
h'OOD: It's true. I've been writing about how recent fashions of the intellectual left are rooted in the golden age of capitalism and all that it produced. But what's characteristic about that postwar boom is that it was atypical. It's just that we happened to grow up in that atypical moment and regarded it as the capitalist norm, so that when it ended, and capitalism showed itself to be what it is, this was a cataclysmic moment in the consciousness of a whole generation. You also have to take into account that the boom created a huge layer of academics with the growth of the universities. The radicals of the sixties were becoming senior professors in the years after the golden age of capitalism ended. People have obviously reacted to all this in many different ways, but one powerful trend has been the tendency to transform politics into a disembodied academic exercise. You know the kind of thing: instead of social revolution carried out by popular struggles, you get textual deconstruction carried out by intellectuals, as if this were the most subversive activity possible.

The world is changing yet again, but I don't know what the consequences will be. It's still early days. I'm a great believer in objective reality impressing itself on consciousness eventually, and things are going on in the world which these intellectual currents can't accommodate. Eruptions of class politics: people, workers, are out in the streets in various parts of the world, in a way that we haven't seen in a long time.

\section{QUESTIONING GLOBALIZATION}

(1: That is a perfect point of departure for us to take up what I think it would be fair to say has been the great debate of your editorial teriure so far, the globalization debate. MR has been taken to task for being an ostrich, sticking its head in the sand, saying that nolhing has changed. A recent article in Race $\mathcal{E}^{\circ}$ Class faulted MR, among others, for "an unthinking adherence to theories and concepts that belonged principally to the industrial period of capitalism that Marx was writing in and about."

WOOD: Look, it's complete rubbish to say that MR's position has been that nothing has changed. MR is famous for talking about ch ınges in capitalism, and it continues to talk about changes. I just don't see how it's possible to say that we have denied that there have been significant changes going on in the nature of capitalism. For example, MR has long been saying things about the current developments in capitalism which other people are suddenly discovering. It's alrnost comical how the financial press is now talking about crises of overcapacity, which MR has been writing about for ages.

We haven't, by the way, spelled out a comprehensive theory of globalization. We've just introduced some critical and cautionary 
notes about how other people have been talking about it. I can only talk about the things I've been emphasizing myself: the assumptions people are making about the state under global capitalism; the assumptions they are making about the unity of the capitalist class under global capitalism; and the treatment of the changes as a distinctive and unique kind of "epochal shift," which I think has all kindsofideologicalimplications.

The assumption that the integration of world capitalism, the existence of transnational companies, and so on, somehow makes the nation-state irrelevant has a lot of implications. It means that the classic target for political struggle is effectively gone from the scene. I've been putting that in question, because I don't think it is true that the state has ceased to be a major player as a result of these trends that people are calling globalization. On the contrary, I think that it has a very essential, absolutely indispensable function in helping capital navigate the global economy. It's just not good enough to call the state irrelevant, to talk about the loss of sovereignty to international organizations of capital. I think all of that is a complete mystification and very politically disabling.

Obviously, this is especially true of the most developed capitalist countries, the U.S. in particular. Less developed countries are obviously subject to the coercions of advanced capitalist states and socalled international agencies like the IMF, although those instruments are of course bound up with the U.S. state. But I don't think it's insignificant that imperialism today takes a different form than it used to, that imperialist states can't just penetrate all borders without working through other, local states. Globalization in one way or another acts through the medium of states. And I think it makes a difference whether states in the third world arc in direct and deliberate collusion with imperial powers and transnational corporations. I do think there are important struggles to be carried on here, which you can't just write off by saying that everything is in the hands of the international organizations and international capital. Of course, new forms of internationalism are vital now, but looking for that internationalism shouldn't become an excuse for giving up on local, national struggles.

The other tendency, to identify globalization with the increasing unity of capital, seems to me rubbish. If globalization means anything, it means increasing contradictions in capital, including the intensification of competition. It also means that the escape routes that capitalism used to have in the form of imperialist expansion by military means, to take formerly non-capitalist areas and absorb them, are not as readily available as they once were, now that capitalism has become more universal. The new forms of imperialism —of debt, of the financial system - are riddled with the internal contradictions of 
capitalism in ways that earlier forms weren't. What we're seeing now in the aftermath of the Asian crisis is a perfect illustration of the deep-seated and completely unresolvable contradictions that come with the universalization of capitalism. In other words, you can't look at the spread of capitalism, the universalization, as simply demonstrating the triumphant power of the system and the foreclosure of opposition to it. You can't just look at the ways the universalization of capitalism inhibits struggle-for instance, by making capital more mobile. Sure, that's true. But you also have to think of it as the universalization of capitalism's contradictions and all the possibilities of struggle that come with that.

Q: Maybe because of some early formulations or the way in which the debate was pitted, people have taken you not merely to be questioning certain assumptions about globalization but to be questioning globalization itself, saying, "It's just the same old capitalism." It occurs to me that you are actually saying that the globe is more capitalist than ever, that capitalism has penetrated areas that it could only dream of penetrating before, but that capital itself is still mostly not global.

WOOD: Well, that's an interesting way of putting it. I think that people do have a tendency to confuse the two. It's important to point out, as others have done, that production still takes place in largely nationally-based companies. It's also important to emphasize, as I've tried to do, that national capitals-especially in advanced capitalist ccuntries like the United States-are still supported by their own nation-states, even when they have a transnational reach. But the persistence of national economies, nationally based capital, nationstates, and so on is completely consistent with what I call the universalization of capitalism: the penetration of the capitalist logic deeper in to the societies of advanced capitalism and spatially throughout the world. By the way, the universalization of capitalism in this sense doesn't mean the universalization of capitalist prosperity, success, industrialization, or development. On the contrary, it can mean the universalization of capitalist polarization, which is, I think, what has happened. One major effect of globalization has been that the countries left on the margins are increasingly impoverished.

Q: What's the difference between positing a change with such enormous ramifications as the one you're now describing and saying that there has been an epochal shift? I realize that you believe that the logic of the system remains the same, only extended across a much greater horizon, whereas the accounts you criticize seem to imply that the logic of capitalism itself has been superseded by some new era. 
On the other hand, you do believe that a gigantic change in the operations of global capitalism has occurred.

WOOD: Yes, massive changes have occurred, but this has been part of a process in capitalism since its inception: the logic of expansion and integration, both vertically and horizontally. So there has to be a reason why you want to designate 1972 as a moment when this happened in some special and new way, the way some people do who talk about globalization as a new epoch. I explicitly said in my very first article on the subject in the pages of Monthly Review that I don't rule out identifying the early 1970 s as a specific moment. I think it has to do with the end of the postwar boom rather than with an epochal shift in the sense that they mean, but I haven't ruled out that something significant happened then. I just think it's more accurate and fruitful to look at it as a long-term process of universalization.

Q: That at the level of the system the continuities are more significant than the discontinuities?

WOOD: Yes, as long as we recognize that the continuities mean constant change and contradiction. But I'm interested in why people feel so driven to identify that particular historical moment as the beginning of a new process. Of course there's been this huge changre, but the history of capitalism has been one of constant change, ani I don't know exactly what is to be gained by identifying that specinic moment, starting in the early 1970 s or whenever, as representing a historical rupture of a qualitatively different kind from the changes that have been occurring in capitalism since its inception.

I don't see it that way. I see constant changes happening at lightniıg speed, and if you want to say that they are accelerating, fine, I accept all of that and think that we have to examine every historical moment in its own specific terms. Yes, of course there are differences, and the re are different political tasks. We may even want to divide capitalism into distinct periods. But there's obviously an important ideological phenomenon in this idea of globalization, which is different from just analyzing change. I've been trying to ask what purpose it is serving in people's minds. Why talk about it in these apocalyptic, epochal terms? To me it's more political than analytical. People claim to be analyziris $g$ change, but to my mind they're not doing a satisfactory job of actually explaining what's been changing in capitalism. I think this obsession with the so-called epochal shift of globalization has more to do with the political trajectory of this generation than with the changes that are actually happening in capitalism. The identification of an epochal shift in the early seventies, at least the way it's talked about now, seen's to me to arise from the disarray in the political and intellectual life of 
the left when the postwar boom came to an end, burying lots of hopes and expectations about the possibilities inherent in capitalism.

\section{CAPITALISM AND SOCIALIST FUTURES}

Q: This actually seems to me the guiding thread of your work: understanding capitalism properly. In books like The Pristine Culture of Capitalism and Democracy Against Capitalism, you analytically distinguish bourgeois from capitalist, modernity from capitalism, and capitalism from earlier kinds of markets. All of that is about clarifying what capitalism is, what makes it a unique social system unlike all prior societies.

WOOD: Yes, that's absolutely right. If there has been one single project in all my intellectual work and in my teaching, it has been to identify the specificity of capitalism, because that seems absolutely central to our political project. Not just recognizing how the system works, which we obviously need to do if we are to mount a struggle ag:tinst it, but also absorbing into our deepest consciousness the idea thit this is a historically specific social form, which means that it has a heginning and an end.

(): And yet a good part of your work has been about historical subjects, such as ancient Greek democracy, that long antedate capitalism.

WOOD: That's not unrelated, of course. I've always thought that the best way to understand capitalism as a specific social form, different from all others, is to situate it in a historical context. We're so immersed in our world that it becomes invisible. And especially now that capitalism has brought the whole world into its orbit, taking a longer historical view is really the only way we can step away from it and get it in focus.

] started working on ancient Greece because I had to teach the subject, and it got me interested, among other things, in the differerices between their conception of democracy and ours. I got interested in the changes that democracy has undergone, especially the changes brought about by capitalism. What I mean is that capitalism makes universal citizenship possible but at the same time makes it less in portant. In precapitalist societies, possessing political rights had very direct and immediate economic implications. In capitalism, it just doesn't. A capitalist doesn't need direct political and military powers to exploit workers the way, for instance, a feudal lord needed them to exploit peasants. And having rights of citizenship doesn't prevent workers from having to sell their labor power for a wage. Feudalism, by definition, was inconceivable with universal citizenship 
rights. Try to imagine feudalism with universal adult suffrage. But capitalism can live with some kind of democracy. The world isn t divided any more between rulers who appropriate the surplus and subjects who produce it. Capitalists and workers are equally citizt:ns. But that's because so much of our life under capitalism goes on in spheres outside the reach of democratic accountability. Capitalist exploitation goes on, and the imperatives of capital accumulation continue to operate, however much democracy there may be in some other, separate political sphere. So capitalism has changed the whole meaning of citizenship and democracy. If we want to achieve a truly democratic society now, it isn't for the most part a matter of extending political rights to people who didn't have them before. It's a question of replacing so-called economic imperatives-not just the direct class power of capital but the coercions of the market-with democratic power.

Or take the history of early modern European political thought, really my main field as a teacher. It's one of the best ways I know to get some critical distance from ideas and values we now take for granted-ideas about property, for instance. There's nothing so revealing, nothing that makes us think again about the things we take for granted, as watching a new set of values, like capitalist conceptions of property, coming into being, replacing other values, especially; when they're being resisted and contested all the way.

You mention my stuff on the difference between bourgeois and capitalist and on the idea of modernity. What I've been trying to do is separate various historical developments that we tend to lump together under the heading of modernity. Some of the things peojele associate with modernity have nothing to do with capitalism. One reason I make these distinctions is just to sharpen our understanding of capitalism, but there are other reasons, too. For one thing, just think of the current postmodernist fashion of dumping on what they call the Enlightenment project, which is supposed to be the hallmark of modernity. Among the things postmodernists want to throw out are a lot of important political, ideological, and cultural victories embodied in that project, a lot of truly emancipatory ideas. I don't think those ideas, so-called Enlightenment ideas, should take the rap for the damage done by capitalism.

Understanding capitalism as a specific social form isn't the strong suit of today's intellectual fashions. People say that postmodernism is the cultural expression of late capitalism. That's obviously right, but it means that these intellectual currents are so absorbed in the realities of capitalism that they can't see it anymore. In that respect, they don't represent much of a challenge to it. Capitalist ideology relies on our taking capitalism for granted as the only possible morle of existence. We live within capitalism as an invisible environment, 
just as we can't see the air we breathe and fish can't see water. I guess what I've tried to do in my historical work is learn to see capitalism.

Q: As capitalism falls out of sight in so many contemporary left thinkers' world views, the flip side is that socialism has nearly disappeared as a political project. There's a different mood now than there was five to eight years ago, when there was a chorus of the "death of socialism," yet we're still inhabiting a moment that is stuck with the legacy of the collapse of the states that were called socialist. What do you think of the possibilities for the renewal of socialism as a political project?

WOOD: The simple answer to that is that as long as capitalism exists, socialism, which is its antithesis, is on the agenda. I have to believe that in this new moment, when the contradictions of capitalism are making themselves manifest in a way that they haven't before, people will notice.

I don't want to underestimate the ways in which the ideological baggage that we bring to this experience obstructs our capacity to perceive what's happening, to deal with it, confront it. I don't want to minimize that. Again, to get back to my generation, we've long lost the habit of thinking in fundamentally anti-capitalist ways, and I would argue that the loss of that habit long predates the collapse of Communism. That generation, or at least its legacy, still dominates the political and intellectual culture of the left. It's going to take a while to play itself out.

Sometimes I think, in my more pessimistic moments, that by the time the objective reality impresses itself on peoples' consciousness, we will have lost the intellectual, political, and organizational resources to take advantage of the moment. But then I think about even worse historical moments, like fascism and the prospect of the left reasserting itself at that time. And we see signs that young people are not satisfied with what the dominant intellectual trends are telling them about the world. And the labor movement has shown signs of taking on board a changing reality.

People are going to have to recognize that the long moment that they thought was typical isn't typical, and that what we've been seeing in the years since then is more what capitalism is about. The possibilities for its improvements are just extremely limited.

Q: In the March 1997 editorial when they brought you on board, Harry and Paul essentially said that you were the answer to the problems of succession and the continuity of the magazine with which they had been grappling. They made an interesting decision to pick you, given your somewhat different political and theoretical back- 
ground. It was a sign of their underlying generosity of spirit and, in a way, typical of the magazine, which is pegged by some people, both supporters and critics, as being much more narrow than it is.

WOOD: I think that's the way you should interpret it. These guys have socialism in their bones, a generosity of spirit, as you say. Anybody who reads their stuff knows how totally commit ted they are to socialism, so that won't come as a surprise. But anyone who has worked with them personally will know whit I mean when I say that they have socialism in their bones. We know a lot of people who can talk the talk, but these people live it. I think it informs all of their waking moments, all of their relationships, in a way that is very uncommon.

Of course, I'm proud that they chose me to work with them, but I hope that the continuity of the magazine doesn't just depend on ine. The audience is reviving. I think we're creating a growing stable of a new generation of writers, in addition to our stalwarts. And that augurs well for the magazine. I'd like to take some credit for it, but I hope that it speaks to the historical moment, that I'm lucky enolgh to have come on to the magazine at a moment when there is a shift in the wind so that there is a potential audience out there ready to hear the kinds of things that MR is saying.

This may sound odd, but I think that this could be MR's real historical moment. It's doing something no one else is doing, at a. time when it needs to be done. In the days when MR was in its golden age, when its circulation was higher than it is now, it may have been unique but it wasn't the only left organ around. Now it's really distinctive and stands almost alone at a time when its message is particularly important. I think that's why we're growing again. Somebody has to keep alive these political and intellectual resources, and I hope we are playing a useful role in that.

May 1999 Marks Pete Seeger's 80th Birthday

Best Wishes, Comrade Pete! 